\title{
Phytoplankton diversity in the Upper Paraná River floodplain during two years of drought (2000 and 2001)
}

\author{
Borges, PAF. ${ }^{\mathrm{a} *}$ and Train, $S \mathrm{.}^{\mathrm{b} *}$ \\ aPrograma de Pós-Graduação em Ecologia de Ambientes Aquáticos Continentais - PEA, \\ Universidade Estadual de Maringá - UEM, \\ Av. Colombo, 5790, CEP 87020-900, Maringá, PR, Brazil

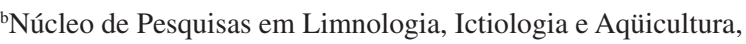 \\ Departamento de Biologia, Universidade Estadual de Maringá - UEM, \\ Av. Colombo, 5790, Bloco H-90, Sala 23, CEP 87020-900, Maringá, PR, Brazil \\ *e-mail: pafborges@gmail.com, train@nupelia.uem.br
}

Received November 20, 2008 - Accepted March 7, 2009 - Distributed June 30, 2009

(With 4 figures)

\begin{abstract}
Floodplain lakes and lotic environments of the High Paraná River floodplain present notable biodiversity, especially in relation to phytoplanktonic community. The goal of this work was to evaluate phytoplankton diversity (alpha, beta and gamma) in three subsystems during two years of drought (2000 and 2001). We sampled 33 habitats at the pelagic zone subsurface during February and August. Due to low hydrometric levels of the Paraná and Ivinhema Rivers, there was no clear distinction between the potamophase and limnophase periods for the two hydrosedimentological cycles analysed. We recorded 366 taxa. The values obtained for gamma diversity estimators ranged from $55.5-87.8 \%$. DCA and variance analyses revealed only spatial differences in the phytoplankton composition. The mean values of species richness, evenness and Shannon diversity were low, especially when compared to those obtained in previous periods for Baía subsystem. The highest mean values of species richness were verified in the connected floodplain lakes. The highest beta diversity was obtained from the Paraná subsystem and lotic environments in 2001. In general, we observed that the Upper Paraná River floodplain has the highest values of species richness, evenness and H' during the potamophase period, when the flood facilitates dispersion. However, this pattern was not observed in 2000 and 2001, years influenced by La Niña. Besides the low precipitation observed during that period, we must consider the influence of the Porto Primavera impoundment, which also altered the discharge regime of the Paraná River by decreasing the degree of connectivity between fluvial channels and the lentic environments of the floodplain. Thus, the prevalence of conditions characterising the limnophase during 2000 and 2001 explains the lack of significant variability registered for most components of phytoplankton diversity over the study period. We conclude that variations in phytoplankton diversity during the study period were related to the absence of conspicuous potamophase, and that observed variations were more closely related to spatial heterogeneity. These results reveal the importance of conservation in the Área de Proteção Ambiental das Ilhas e Várzeas do Rio Paraná, with its subsystems and diverse aquatic habitats.
\end{abstract}

Keywords: Phytoplankton, diversity, connectivity, spatial and temporal variability, conservation.

\section{Diversidade fitoplanctônica da planície de inundação do Alto Rio Paraná em dois anos de seca (2000 e 2001)}

\section{Resumo}

Os lagos de inundação e ambientes lóticos da planície de inundação do Alto Rio Paraná apresentam notável biodiversidade, especialmente em relação à comunidade fitoplanctônica. Com o objetivo de avaliar a diversidade fitoplanctônica (alfa, beta e gama) desse sistema em dois anos de seca (2000 e 2001), 33 ambientes foram estudados. As amostragens foram efetuadas à subsuperfície da zona pelágica, nos meses de fevereiro e agosto. Não ocorreu nítida distinção entre os períodos de potamofase e limnofase nos dois ciclos hidrossedimentológicos. Foram inventariados 366 táxons. Os valores obtidos para os estimadores de diversidade gama variaram de 55,5 a 87,8\%. A DCA e as análises de variância efetuadas evidenciaram apenas variação espacial na composição fitoplanctônica. Os valores de riqueza de espécies, eqüitabilidade e H' foram baixos, especialmente quando comparados aos obtidos em períodos anteriores para o subsistema rio Baia. Os maiores valores médios de riqueza de espécies foram registrados nas lagoas com conexão. A diversidade beta foi maior no ano de 2001, no subsistema Paraná e nos ambientes lóticos. Em geral, na planície de inundação do Alto rio Paraná, os maiores valores de riqueza de espécies, eqüitabilidade e diversidade de Shannon são 
observados no período de potamofase, quando a inundação facilita a dispersão, todavia, este padrão não foi evidenciado no presente estudo. Além da baixa precipitação ocorrida no período, deve ser considerada a influência da construção da barragem de Porto Primavera, que modificou também o regime de descarga do Rio Paraná e diminuiu o grau de conectividade entre os canais fluviais e os ambientes lênticos da planície. Assim, a prevalência de condições que caracterizam a limnofase durante os anos de 2000 e 2001 explica o fato de não terem ocorrido diferenças significativas para a maioria dos componentes da diversidade fitoplanctônica quanto aos períodos de estudo. Conclui-se que a variabilidade da diversidade fitoplanctônica no presente estudo esteve relacionada à ausência de potamofase conspícua, e que as variações nos atributos de diversidade fitoplanctônica estiveram relacionadas à heterogeneidade espacial. Os resultados obtidos reforçam a necessidade de medidas visando à conservação da Área de Proteção Ambiental das Ilhas e Várzeas do Rio Paraná, com seus diversos subsistemas e tipos de hábitats.

Palavras-chave: Fitoplâncton, diversidade, conectividade, variabilidade espacial e temporal, conservação.

\section{Introduction}

Floodplains are ecosystems dominated by disturbance regimes that promote high spatial and temporal variability, alter the species succession, allow the occurrence of ecotones, lead to changes in the degree of connectivity between biotopes and the main river, thus maintaining high biodiversity (Neiff, 1990; Ward et al., 1999).

The hydrosedimentological regime has been identified as the main factor acting on aquatic communities in floodplains by determining distinct patterns of development during cycle phases. The flow of matter and energy occur as pulses, either periods of potamophase (flooding or high water) or limnophase (dry or low water). Potamophase periods homogenise aquatic environments in these systems (Neiff, 1990). Phytoplankton community in floodplain lakes is complex in composition and species richness, a complexity strongly influenced by the pulses that occur in both phases of the hydrosedimentological cycle (Train and Rodrigues, 2004).

Even though the Upper Paraná River floodplain has suffered due to human occupation and the effects of flow regulation imposed by upstream dams (Carvalho, 2007; Agostinho et al., 2008), it still plays a key role in maintaining regional biotic diversity as the only remnant várzea from the Paraná River in the Brazilian territory (Agostinho et al., 2007).

Most studies on phytoplankton community in Brazilian floodplains have focused mainly on the spatial and temporal variability of composition, density, and biomass as functions of environmental factors, especially the hydrosedimentological regime (Melo and Huszar, 2000; Train and Rodrigues, 1998; 2004; Nabout et al., 2006; Bovo-Scomparin and Train, 2008). Only Nabout et al. (2007) focused exclusively on phytoplankton diversity. Similarly, the study presented here analysed the phytoplankton diversity of the Upper Paraná River floodplain. The following hypotheses were tested: i) phytoplankton diversity varies among the several subsystems and habitat types in the Upper Paraná River floodplain; ii) species richness is highest in habitats directly connected to rivers due to the greatest exchange of algae in- nocula; and iii) beta diversity is highest during periods of intense drought, when heterogeneity among habitats increases.

\section{Material and Methods}

\subsection{Study area}

The Upper Paraná River floodplain (Figure 1) is $230 \mathrm{~km}$ long and $20 \mathrm{~km}$ wide, with flooded areas covering active and semi-active channels, floodplain lakes, elongated lowlands associated with paleochannels or the watershed, and backwaters or ressacos (Souza Filho and Stevaux, 2004). The last environment type constitutes lentic water bodies, originated by the recently abandoned channels formed by lateral bars (Souza Filho and Stevaux, 2004). In this study, such relic channels were considered as "connected floodplain lakes" since they present a similar morphology and hydrology.

We considered three microbasins in this stretch of the Upper Paraná River floodplain: the Ivinhema, Baía and Paraná subsystems. According to Thomaz et al. (2004a), the interactions between these main rivers and the floodplain lakes are specific to each subsystem.

Despite the interannual variability of existing hydrological cycles, high hydrometric levels and high precipitation predominate between November to May, and low hydrometric levels and low precipitation predominate between June and October (Thomaz et al., 2004b; Souza-Filho and Stevaux, 2004).

\subsection{Field and laboratory methods}

Total phytoplankton samples were collected in 11 environments from each of the three subsystems selected for this study (Ivinhema, Baía and Paraná) in the Upper Paraná River floodplain, yielding a total of 33 biotopes (Figure 1). Sampling was from the subsurface of the pelagic zone in each environment during the rainy period, when normally the potamophase occurs (February 2000 and 2001) and during the dry period, when the limnophase occurs (August 2000 and 2001). The limnologi- 


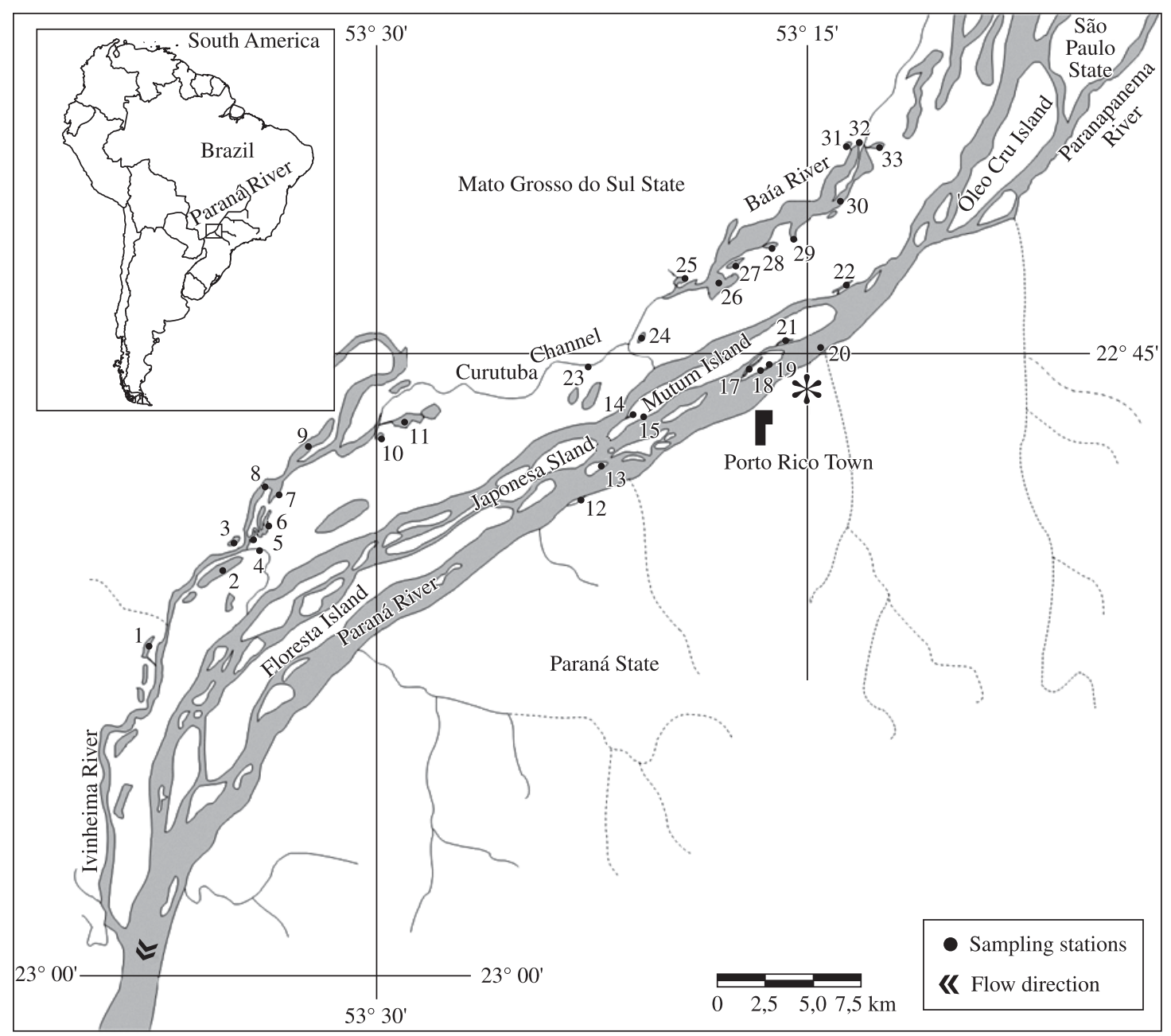

Figure 1. Map of the Upper Paraná River floodplain, with locations of sampled environments in each subsystem: Ivinhema subsystem (1 - Peroba Lake; 2 - Ventura Lake; 3 - Zé do Paco Lake; 4 - Ipoitã Channel; 5 - Boca do Ipoitã Lake; 6 - Patos Lake; 7 - Capivara Lake; 8 - Ivinhema River; 9 - Finado Raimundo Lake; 10 - Jacaré Lake; 11 - Sumida Lake); Paraná subsystem (12 - Cortado Channel; 13 - Pombas Lake; 14 - Manezinho Backwater; 15 - Osmar Lake; 16 - Bilé Backwater; 17 - Leopoldo Backwater; 18 - Clara Lake; 19 - Pousada Lake; 20 - Paraná River; 21 - Pau Velho Backwater; 22 - Garças Lake); Baía subsystem (23 - Curutuba Channel; 24 - Traíra Lake; 25 - Guaraná Lake; 26 - Baía River; 27 - Fechada Lake; 28 - Pousada das Garças Lake; 29 - Porcos lake; 30 - Baía Channel; 31 - Maria Luiza Lake; 32 - Gavião Lake; 33 - Onça Lake).

cal variables, phytoplankton attributes, and respective methodologies employed are listed in Table 1.

\subsection{Data analyses}

To summarise phytoplankton composition data, we used the Detrended Correspondence Analysis (DCA Gauch Jr., 1986; Jongman et al., 1995). This analysis was made using presence (1) and absence (0) data for species in the all the different habitats and periods explored in this study.

A variance analysis (two-way ANOVA) was applied to test differences in species composition. This was summarised by taking the mean of scores for DCA axes retained for interpretation, and the mean of community attributes (species richness, H' and evenness) in each subsystem (factor 1) and habitat type (channels, connected and isolated floodplain lakes and rivers; factor 1) during different study periods (rainy and dry; factor 2).

The assumptions of normality and homocedasticity were evaluated through Shapiro-Wilk and Levene tests, respectively. When the ANOVA detected significant differences $(p<0.05)$ and the interaction between the factors was not significant, we used a posteriori Tukey test. The variance analyses were performed using Statistica version 7.1 (StatSoft Inc., 2005), while species richness, evenness, H' and DCA were obtained using Pc-Ord 4.0 (McCune and Mefford, 1999). 
Table 1. Methods used in analyses of physical and chemical variables and phytoplankton attributes.

\begin{tabular}{|c|c|c|}
\hline Variables & Method/equipment & Author/source \\
\hline Water temperature $(\mathrm{T})$ & Thermistor coupled to an oximeter & \\
\hline Dissolved oxygen $\left(\mathrm{O}_{2}\right)$ & Portable digital oximeter & \\
\hline Euphotic zone $\left(\mathrm{Z}_{\mathrm{eu}}\right)$ & Radiometer & \\
\hline Electric conductivity (Cond) & Portable digital conductivimeter & \\
\hline $\mathrm{pH}$ & Portable digital pHmeter & \\
\hline Turbidity (turb) & Turbidimeter & \\
\hline Total phosphorus (TP) & Spectrophotometer & Golterman et al. (1978) \\
\hline $\begin{array}{l}\text { Soluble reactive phosphorus } \\
\text { (SRP) }\end{array}$ & Spectrophotometer & Golterman et al. (1978) \\
\hline Total nitrogen $(\mathrm{TN})$ & Spectrophotometer & Mackereth et al. (1978) \\
\hline Nitrate $\left(\mathrm{NO}_{3}\right)$ & Spectrophotometer & Giné et al. (1980) \\
\hline Ammonium $\left(\mathrm{NH}_{4}^{+}\right)$ & Spectrophotometer & Mackereth et al. (1978) \\
\hline $\begin{array}{l}\text { Precipitation (Prec) and } \\
\text { Fluviometric level }\end{array}$ & $\begin{array}{l}\text { Hydrometric station located next to Porto São José } \\
\text { in Paraná River and Porto Sumeca in Ivinhema } \\
\text { River. }\end{array}$ & $\begin{array}{l}\text { Agência Nacional de } \\
\text { Águas (ANA) and Itaipu } \\
\text { Binacional }\end{array}$ \\
\hline Phytoplankton density & $\begin{array}{l}\text { Counting in random fields (mean of } 100 \text { fields by } \\
\text { sample), under inverse microscope. }\end{array}$ & Utermöhl (1958) \\
\hline Phytoplankton biomass & $\begin{array}{l}\text { Phytoplanktonic biovolume obtained by multiplying } \\
\text { the population density by the volume of individuals. }\end{array}$ & \\
\hline Cell volume & $\begin{array}{l}\text { Stereometric appropriate formula to the form of } \\
\text { algae cells. }\end{array}$ & $\begin{array}{l}\text { Edler (1979); Wetzel and } \\
\text { Likens (2000) }\end{array}$ \\
\hline Species richness & Number of species by sample. & \\
\hline $\begin{array}{l}\text { Shannon-Wiener diversity }\left(\mathrm{H}^{\prime}\right) \\
\text { and evenness }\end{array}$ & Calculated based on biovolume data. & $\begin{array}{l}\text { Shannon and Weaver } \\
\text { (1963) }\end{array}$ \\
\hline Beta diversity $(\beta-2)$ & $\begin{array}{l}\text { Calculated based on data of presence/absence of } \\
\text { species, according to the formula: } \\
\beta 2=\left[\left(\mathrm{R} / \alpha_{\max }\right)-1\right] /[\mathrm{n}-1]\end{array}$ & Harrison et al. (1992) \\
\hline Gamma diversity & $\begin{array}{l}\text { Non-parametric estimators - Jackknife } 1 \text { e } 2 \text {, } \\
\text { Chao } 2, \text { ICE and Bootstrap - based on incidence } \\
\text { data (presence/absence) using EstimateS software. }\end{array}$ & $\begin{array}{l}\text { Chazdon et al. (1998); } \\
\text { Colwell (1997) }\end{array}$ \\
\hline
\end{tabular}

\section{Results}

During the study period, rainy and dry periods were indistinct in the Upper Paraná River, especially in 2000 (Figure 2). However, during 2001, we observed a remarkable decrease in precipitation between June and September. The hydrometric levels of the Paraná and Ivinhema rivers were generally low during both years (see Souza Filho, 2009), but in 2001 they were still minor (Figure 2). For both the Paraná River and Ivinhema River, the values recorded were generally below the flooding limits for the várzea adjacent to these rivers, i.e., $3.5 \mathrm{~m}$ for the Paraná River and $2.75 \mathrm{~m}$ for the Ivinhema River.

The lowest mean values of water temperature and depth in the three subsystems were observed during August (2000 and 2001). In general, the environments connected to the Paraná River presented high mean values of electric conductivity, Zeu and $\mathrm{NO}_{3}$, whereas high mean concentrations of TN, TP and SRP were registered in the Baía and Ivinhema subsystems. The latter also pre- sented high mean values of turbidity. More details about abiotic variables can be found in Thomaz et al. (2004a). The sum of all variation coefficients from sampled variables was high for the Paraná subsystem (959.8), indicating high variability among environments connected to this river. The sum of all variation coefficients from the Ivinhema subsystem was 908, and the Baia subsystem was 926.9.

We identified 366 taxa distributed among 9 taxonomic groups: Chlorophyceae (123), Euglenophyceae (66), Zygnemaphyceae (53), Bacillariophyceae (51), Cyanobacteria (40), Xanthophyceae (16), Chrysophyceae (8), Cryptophyceae (6) and Dinophyceae (3). The Trachelomonas genus presented the highest number of species. The obtained values for species richness estimators (gamma diversity) were representative for the observed number, with percentages varying from 55.5 to $87.8 \%$ (Table 2). The Bootstrap estimator best reflected the richness observed.

The two first axes from DCA were retained for interpretation because they explained the greater variability 


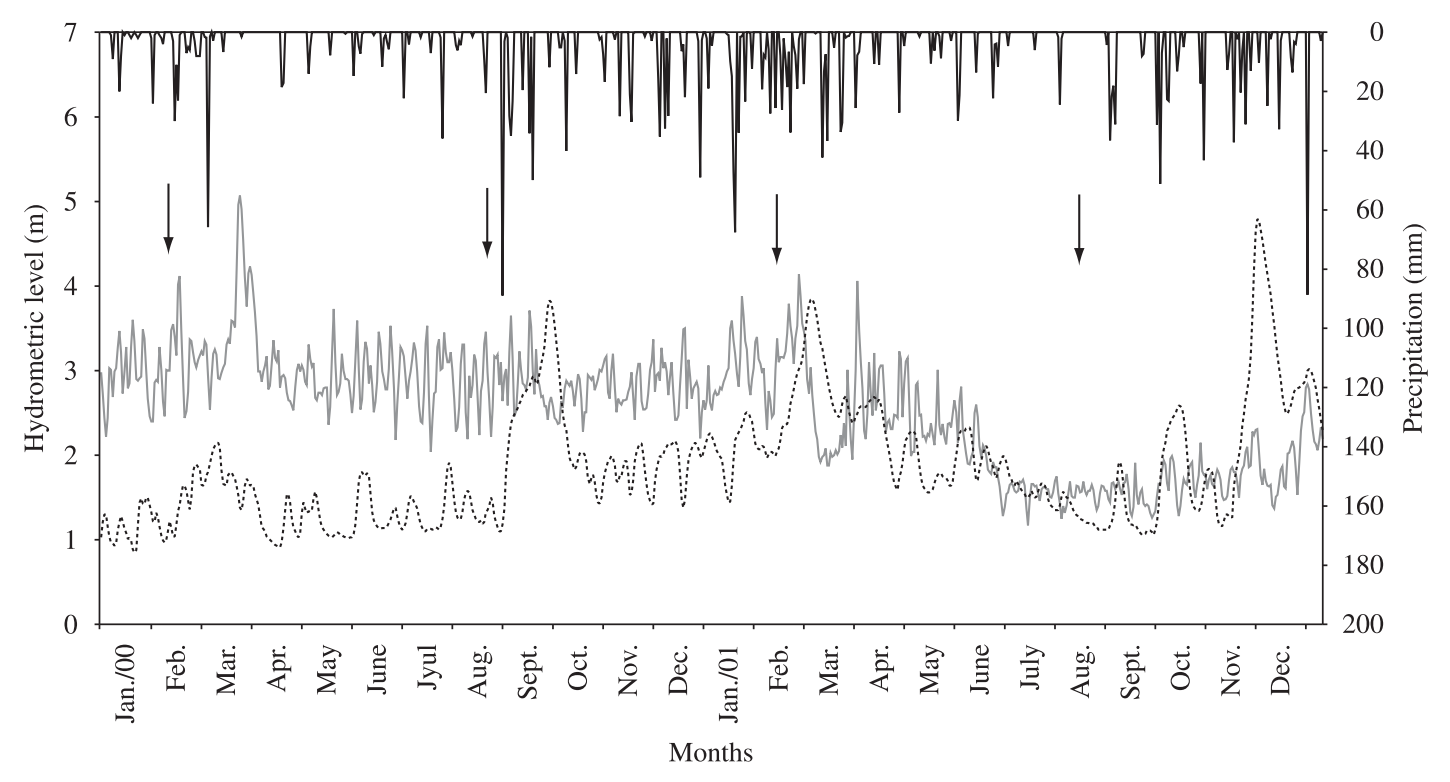

— Precipitation _ Paraná River

...... Ivinhema River

Figure 2. Pluviometric precipitation and hydrometric levels of Paraná and Ivinhema rivers in 2000 and 2001. Arrows indicate sampling periods.

Table 2. Gamma diversity for both studied years, registered by period with values of non-parametric estimators (Jackknife 1 and 2, Chao 2, ICE and Bootstrap) according to relative contribution (\%).

\begin{tabular}{lcccccc}
\hline & $\begin{array}{c}\text { Observed } \\
\text { gamma } \\
\text { diversity }\end{array}$ & $\mathbf{S}_{\text {Jackknife1 }}$ & $\mathbf{S}_{\text {Jacknife2 }}$ & $\mathbf{S}_{\text {Chao2 }}$ & $\mathbf{S}_{\text {ICE }}$ & $\mathbf{S}_{\text {Bootstrap }}$ \\
\hline Feb00 & 225 & $325.9(69.1 \%)$ & $396.2(56.8 \%)$ & $405.3(55.5 \%)$ & $380.6(59.1 \%)$ & $267.5(84.1 \%)$ \\
Aug00 & 180 & $262.4(68.6 \%)$ & $312.2(57.6 \%)$ & $289.5(62.2 \%)$ & $316.2(56.9 \%)$ & $215.6(83.5 \%)$ \\
Feb01 & 236 & $339.8(69.4 \%)$ & $407.5(57.9 \%)$ & $395.1(59.7 \%)$ & $394.6(59.8 \%)$ & $280.5(84.1 \%)$ \\
Aug01 & 188 & $261.5(71.9 \%)$ & $310.1(60.6 \%)$ & $303.5(61.9 \%)$ & $286.7(65.6 \%)$ & $219.9(85.5 \%)$ \\
Whole period & 366 & $477.2(76.7 \%)$ & $532.7(68.7 \%)$ & $478.1(76.6 \%)$ & $475.1(77.1 \%)$ & $416.7(87.8 \%)$ \\
\hline
\end{tabular}

of data (eigenvalues 0.33 and 0.26 , respectively). The dispersion of scores from locals along the two first DCA axes did not reveal differences in species composition for the sampling period in the three subsystems (Figure 3), and neither did variance analysis (Table 3).

Both the ANOVA and scores dispersion in the DCA diagram revealed differences in phytoplankton composition in the three subsystems. In the DCA diagram, the Ivinhema subsystem was separated to the left, the Baía subsystem was more central, and the Paraná subsystem was on the right. Differences in phytoplankton composition for habitat types were clearly highlighted only in the variance analyses. Axis 1 of DCA distinguished rivers and channels from disconnected floodplain lakes, and the second axis separated floodplain lakes from channels.

The mean values of phytoplankton species richness were relatively low with generally less than 30 taxa
(Figure 4a). In the Paraná subsystem, the highest mean value of for this attribute was registered in February 2000, whereas for the Ivinhema and Baía subsystems, the highest value occurred in February 2001. Among habitat types, the highest values of species richness was recorded in February, and the lowest in August of both years with the exception of rivers (Figure 4b).

The variance analyses indicated significant differences among study periods, among subsystems, and also among habitat types (Table 3). In general, species richness presented the highest mean values during rainy periods in environments of the Paraná subsystem, followed by Baía and Ivinhema. The Tukey test revealed significant differences between Paraná and Ivinhema subsystems. Species richness had high values in connected floodplain lakes, followed by disconnected flood- 


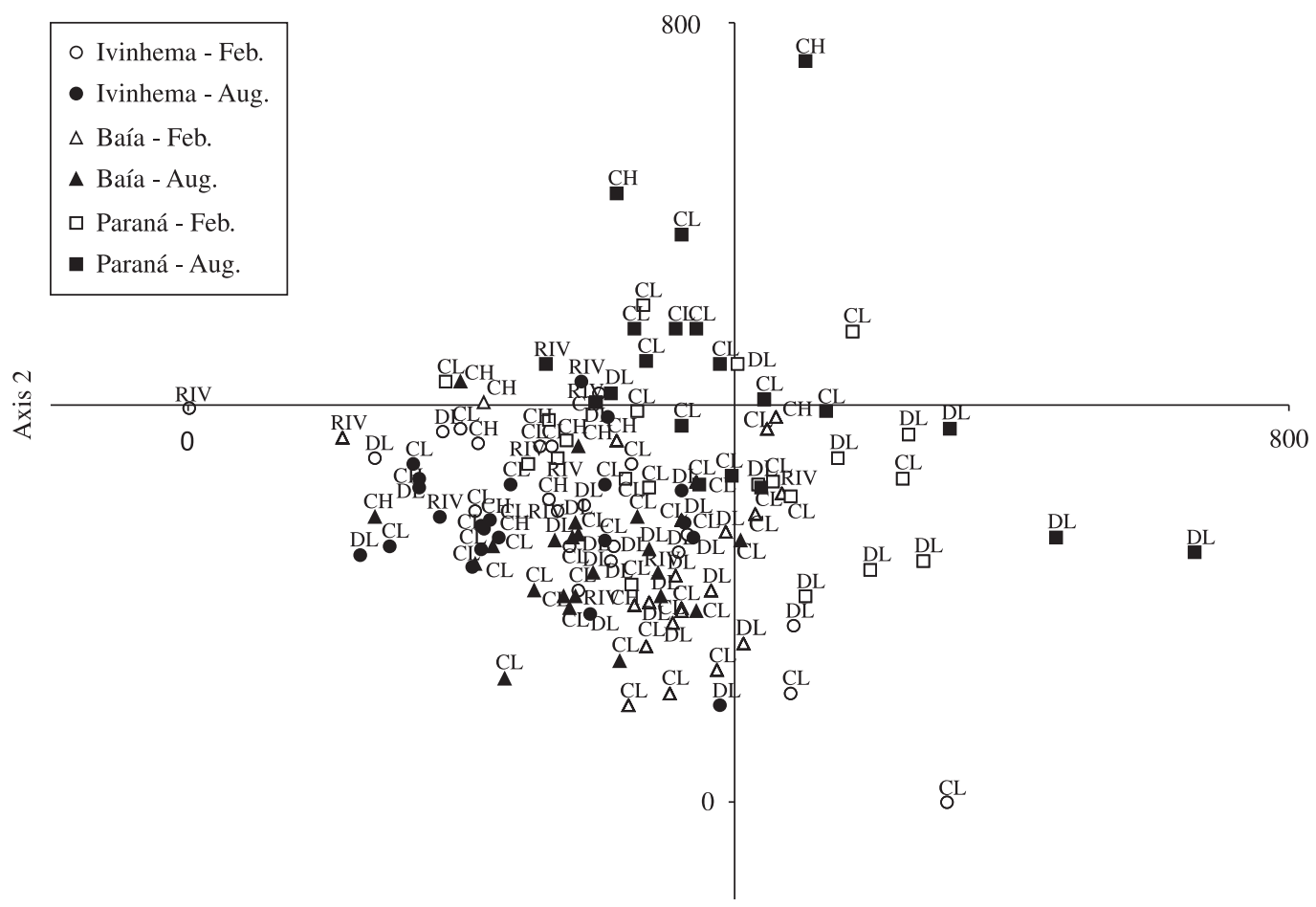

Axis 1

Figure 3. Scores of sampled locals (CL - connected floodplain lakes; DL - disconnected floodplain lakes; $\mathrm{CH}$ - channels and RIV-rivers) along the two first DCA axes, for the Ivinhema, Baía and Paraná subsystems in the study period (February - Feb and August - Aug).

plain lakes, rivers and channels, with the latter showing different values from connected lakes.

Table 3 the mean evenness values were generally low (40-70\%) with the lowest values recorded in February 2001 in the Baía subsystem (Figure 4c). In the Ivinhema subsystem, the highest mean values occurred in August, while the Baía subsystem showed a decrease between February 2000 and February 2001. For the Paraná subsystem, the evenness presented an increasing trend over the studied months. In general, evenness was high in habitats connected to the Paraná and Ivinhema rivers, with significant differences between the Baía subsystem and the others. But during the study period, significant differences were unverified (Table 3 ).

Shannon-Wiener diversity presented relatively low mean values close to 2.0 bits. $\mathrm{mm}^{-3}$ (Figure $4 \mathrm{e}$ ). The lowest mean values occurred in the Baía subsystem, except during February $2000\left(\mathrm{H}^{\prime}>1.5\right.$ bits. $\left.\mathrm{mm}^{-3}\right)$. In the Ivinhema subsystem, the lowest mean value was observed in February 2000. There was a trend of increasing H' values in the Paraná subsystem over the entire twoyear study period. The ANOVAs performed for H' values did not show significant differences in the study periods, but H' was high in the subsystems tested, with a descending order in the environments connected to the Paraná,
Ivinhema, and Baía rivers and a significant difference between Baía and Paraná (Table 3).

The mean values for evenness and $\mathrm{H}^{\prime}$ in different habitat types showed high temporal variation in rivers and channels, with the lowest mean value in February 2001 (Figures 4d and f). For evenness, rivers presented the highest mean values, whereas for H' the highest values were in connected lakes, followed by rivers, isolated floodplain lakes, and channels. The variance analyses did not show significant difference for these two attributes about the connectivity degree of environments (Table 3).

In all sampled habitats from the Upper Paraná River floodplain, the beta diversity values were low, with higher values recorded in 2001 (5.5\%) compared to 2000 $(4.2 \%)$. The mean values of beta diversity, both spatial and temporally, were similar among the different subsystems analysed, with values slightly higher for the environments associated with the Paraná subsystem, followed by the Ivinhema and Baía subsystems (Figure 4g). In relation to the degree of connectivity between habitats, high values of beta diversity (on both spatial and temporal scales) typically occurred in channels, followed by rivers, and connected and disconnected lakes (Figure 4h). 
Table 3. ANOVA two-way results for phytoplankton community composition as represented in scores of two first DCA axes, and regarding the attributes of phytoplankton diversity (Species richness, Evenness and Shannon-Wiener diversity). $\mathrm{DF}=$ degree of freedom; $\mathrm{F}=$ value of $\mathrm{F}$ statistic for the adopted significance level; $\mathrm{p}=$ significance level $(\mathrm{p}<0.05)$. Bold values indicate significant differences.

\begin{tabular}{|c|c|c|c|c|}
\hline Variables & Effects & DF & $\mathbf{F}$ & $\mathbf{p}$ \\
\hline \multirow[t]{6}{*}{ DCA 1} & Period & 1 & 2.927 & 0.0896 \\
\hline & Subsystem & 2 & 21.232 & 0.0000 \\
\hline & Period $*$ Subsystem & 2 & 2.573 & 0.0804 \\
\hline & Period & 1 & 0.4289 & 0.5138 \\
\hline & Habitat type & 3 & 6.6401 & 0.0003 \\
\hline & Period $*$ Habitat type & 3 & 0.7754 & 0.5099 \\
\hline \multirow[t]{6}{*}{ DCA 2} & Period & 1 & 2.766 & 0.0988 \\
\hline & Subsystem & 2 & 28.957 & 0.0000 \\
\hline & Period $*$ Subsystem & 2 & 3.180 & 0.0450 \\
\hline & Period & 1 & 1.1216 & 0.2917 \\
\hline & Habitat type & 3 & 5.7501 & 0.0010 \\
\hline & Period $*$ Habitat type & 3 & 0.3987 & 0.7542 \\
\hline \multirow[t]{6}{*}{ Species richness } & Period & 1 & 5.0240 & 0.0268 \\
\hline & Subsystem & 2 & 5.4153 & 0.0056 \\
\hline & Period $*$ Subsystem & 2 & 0.3188 & 0.7276 \\
\hline & Period & 1 & 3.6955 & 0.0568 \\
\hline & Habitat type & 3 & 3.0899 & 0.0297 \\
\hline & Period $*$ Habitat type & 3 & 0.4097 & 0.7463 \\
\hline \multirow[t]{6}{*}{ Evenness } & Period & 1 & 0.803 & 0.3721 \\
\hline & Subsystem & 2 & 6.508 & 0.00212 \\
\hline & Period $*$ Subsystem & 2 & 0.874 & 0.4199 \\
\hline & Period & 1 & 2.8358 & 0.0947 \\
\hline & Habitat type & 3 & 0.4771 & 0.6988 \\
\hline & Period $*$ Habitat type & 3 & 1.0864 & 0.3576 \\
\hline \multirow{6}{*}{$\begin{array}{l}\text { Shannon-Wiener } \\
\text { Diversity }\end{array}$} & Period & 1 & 0.065 & 0.7999 \\
\hline & Subsystem & 2 & 5.154 & 0.0071 \\
\hline & Period $*$ Subsystem & 2 & 0.942 & 0.3928 \\
\hline & Period & 1 & 0.4266 & 0.5149 \\
\hline & Habitat type & 3 & 1.4690 & 0.2263 \\
\hline & Period $*$ Habitat type & 3 & 1.1654 & 0.3259 \\
\hline
\end{tabular}

\section{Discussion}

In the two-year study period, there were no conspicuous periods of flooding or potamophase in the Upper Paraná River floodplain due to low hydrometric levels of the Paraná and Ivinhema rivers. Thus, the results confirm that hydrometric values of Paraná River less than $3.5 \mathrm{~m}$ are not enough to flood the lentic habitats of the várzea proximate to this river, and hydrometric levels in excess of $4.6 \mathrm{~m}$ in the Paraná River are necessary to cause flooding in the várzea close to Ivinhema River (Rocha, 2002; Thomaz et al., 2004b). Furthermore, during the months when the samplings were undertaken, the hydrometric levels of the Ivinhema River was always lower than
$2.75 \mathrm{~m}$, which according to Rocha (2002) is the initial limit for this river to flood the várzea of its microbasin.

Thus, during 2000 and 2001, lentic habitats did not suffer flooding and the hydrosedimentological cycles of Paraná and Ivinhema rivers were always under limnophase, as previously stated by Train et al. (2004) and Thomaz et al. (2004a).

In the Ivinhema River microbasin, low precipitation was the main factor responsible for the low hydrometric levels recorded in this river. To explain the low hydrometric levels of the Upper Paraná River observed during 2000 and 2001, we must consider low precipitation in addition to the influence of upstream reservoirs. Due to the energetic crisis occurring in this period, a significant amount of water was retained for electricity production 

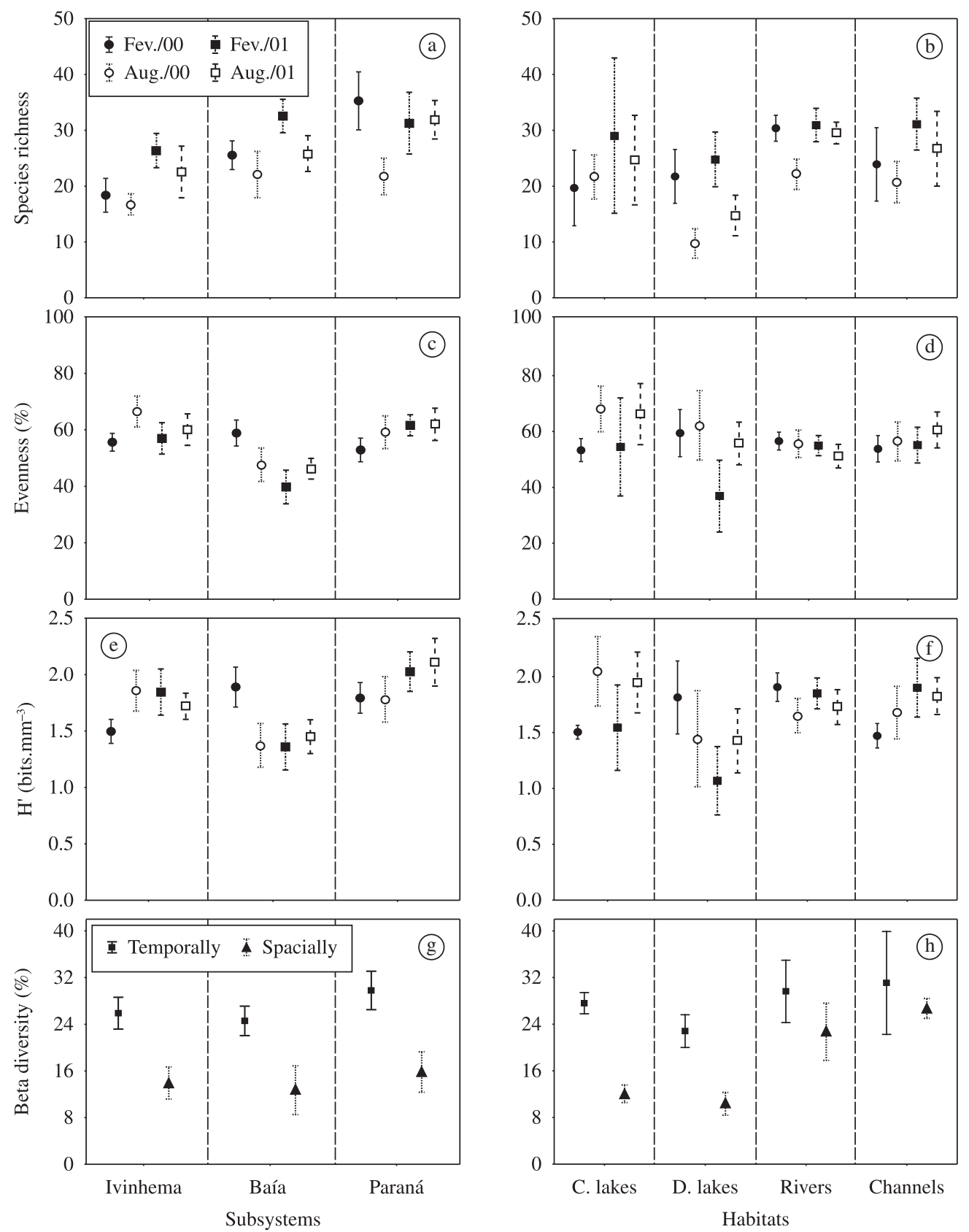

Figure 4. Species richness (a), evenness (c), H' (e), and temporal and spatial beta diversity (g) for all sampled environments in the Ivinhema, Baía and Paraná subsytems. Also species richness (b), evenness (d), H' (f) and temporal and spatial beta diversity (h) for each sampled habitat type (rivers, channels, connected - C. lakes - and disconnected floodplain lakes - D. lakes) in the three analyzed subsystems in the Upper Paraná River floodplain. (Mean +/- standard error).

by the reservoirs. This study was conducted immediately after the impoundment of the Porto Primavera Reservoir, and the reservoir had completed filling at the beginning of 2001 (Souza-Filho et al., 2004). Low precipitation in this period was probably due to the influence of La Niña phenomena (McPhaden et al., 2006), which cause negative anomalies in precipitation in the Paraná River basin.
The total number of recorded phytoplankton taxa was high and similar to diversity discovered in other Brazilian floodplains (Melo and Huszar, 2000; Nabout et al., 2006; 2007). However, the total taxa number (366) was lower than that registered by Train et al. (2004) for the same environments and period (450 taxa). This is because these researchers performed additional samplings 
near littoral zones in each environment, many containing extensive stands of aquatic macrophytes (Thomaz et al., 2004c). Accordingly, they reported higher occurrences of tikoplanktonic and metaphytic taxa.

Chlorophyceae was the most specious group, typically represented by cosmopolite species as previously observed in several environments from the Paraná River basin (Train and Rodrigues, 2004; Train et al., 2005; Borges et al., 2008; Bovo-Scomparin and Train, 2008). Euglenophyceae was the second major group contributing to diversity and is also known to be common in lentic, shallow, organic-rich environments (Jati and Train, 1994; Train et al., 2004). This group may have been favoured by low hydrometric levels resulting from the prevalence of limnophase conditions in all floodplain lakes.

Due to the difficulty of collecting all species in taxonomic surveys, it is necessary to calculate gamma diversity data based on estimators (Bini et al., 2001). The values for the diversity estimators used here indicate that the obtained samples were sufficient and representative since percentages were equal or greater than $80 \%$. These results were similar to those for the Araguaia River floodplain (Nabout et al., 2007).

Meanwhile, the phytoplankton diversity throughout the study area is higher when more intensive surveys are considered, both in spatial and temporal scales (Train et al., 2004; Train et al., 2007). Thus, estimators that considered high species number for the region, such as ICE and Sjack $_{2}$, best expressed the gamma diversity of the phytoplankton community in the Upper Paraná River floodplain. We highlight the importance of using these estimators and of conducting more intense taxonomic surveys on the phytoplankton community in this floodplain.

In general, the flood pulses that characterise the potamophase have a homogenising effect on aquatic habitats in the Upper Paraná River floodplain. During this phase, scientists have observed high values of species richness, evenness, and $\mathrm{H}^{\prime}$ of phytoplankton and other aquatic communities (Train et al., 2004; Velho et al., 2004; Alves et al., 2005; Bonecker et al., 2005; Thomaz et al., 2007). In this period, flooding permits the exchange of algae innocula between environments, increases nutrient availability, increases niche opportunity. Flooding also decreases the dominance of phytoplankton species and consequent exclusive competition, favouring the flourishing of different taxa, with increasing numbers of rare species (Train and Rodrigues, 2004). In the present study, however, this pattern was not clearly observed. This may be explained by the absence of conspicuous potamophase, since Train et al. (2004) observed high values of phytoplankton biomass with the dominance of only a few species (namely cyanobacteria) in many of these environments in February of 2000 and 2001.

Hydrometric levels rising above $3.5 \mathrm{~m}$ for the Paraná River occurred on only 26 days in 2000, and 11 days in 2001 (Souza Filho, 2009). Thus the prevalence of conditions characterising the limnophase explains the lack of significant variability for the phytoplankton attributes analysed in the study period, except for species richness. However, significant differences were observed for diversity attributes among subsystems and environment types. This emphasises the importance of preserving the microbasin subsystems of the High Paraná River floodplain, environments with distinct limnological features and several degrees of connectivity between main rivers and floodplain habitats.

According to Harrison et al. (1992), high environmental variability is associated with an increase in the beta diversity, as confirmed by our study for phytoplankton. Biotopes associated with the Paraná River presented the highest mean values of beta diversity and the highest values of coefficient of variation of abiotic variables. Studies on aquatic macrophytes in this system also revealed high values of beta diversity for the Paraná subsystem, which coincided with high environmental variability (Bini et al., 2001; Thomaz et al., 2004c).

In this way, the high species richness, H', and beta diversity of phytoplankton recorded in environments associated with the Paraná subsystem suggest despite the low depth and small area of most floodplain lakes, they must be included in the management plans of the Área de Proteção Ambiental das Ilhas e Várzeas do Rio Paraná, as previously advocated by Bini et al. (2001) and Thomaz et al. (2004c).

The highest values of beta diversity observed in 2001 were probably due to the intense dry period that occurred as a result of La Niña. In turn, this coincided with low hydrometric levels which isolated the studied environments and resulted in significant phytoplankton diversity among habitats.

We recorded high species richness values for phytoplankton in connected lakes, and this increase in phytoplankton biodiversity emphasises the importance of connectivity for the exchange of species between floodplain lakes and rivers, as described previously for phytoplankton (Train and Rodrigues, 2004) and zooplankton (Alves et al., 2005; Bonecker et al., 2005; Aoyagui, 2006) in this system.

The highest beta diversity values and the greatest temporal variation of evenness and $\mathrm{H}^{\prime}$ in rivers and channels is likely related to the high flushing rate and consequent low retention time of water in lotic systems that become more instable. Similar results were also reported for rotifer assemblages in this study period (Aoyagui, 2006).

The diversity of disturbance regimes promotes conditions for a great variety of organisms, and maximising phytoplankton diversity in the Upper Paraná River floodplain is of paramount importance because it promotes interactivity between principal channels and associated environments. The mean values obtained for certain diversity attributes (such as species richness and $\left.H^{\prime}\right)$ were lower than previously recorded in the Baía subsystem during a typical hydrosedimentological cycle featuring potamophase and limnophase periods (Train 
and Rodrigues, 2004). This indicates that the absence of potamophase decreases connectivity between the main river and various habitats, which may be responsible for the decrease in phytoplankton diversity in the Upper Paraná River floodplain, principally in Baía subsystem.

The results reinforce the importance of considering spatial scales when studying the dynamics of phytoplankton diversity, and they also indicate that local factors structure the diversity of phytoplankton in this floodplain. Future studies considering measurements of geographic distances and degrees of connectivity between the habitats will better resolve the mechanisms regulating local and regional diversity of phytoplankton community in floodplains.

As predicted in our hypothesis, we conclude that variability in phytoplankton diversity during 2000 and 2001 was related to the absence of floods, and variations in attributes of phytoplankton diversity were related to spatial heterogeneity. Also accurate were our predictions of finding the highest species richness in floodplain lakes directly connected to rivers, and of observing high beta diversity during periods of intense drought. There is a pressing need for measures promoting the conservation of Área de Proteção Ambiental (APA) das Ilhas e Várzeas do rio Paraná, with its diverse subsystems and habitat types. To maintain the rich biodiversity of this region, management of this area must encompass control over the operational procedures of upstream dams, and economical and social interests must be balanced with environmental issues.

Acknowledgements - The authors are grateful to the Núcleo de Pesquisas em Limnologia, Ictiologia e Aqüicultura (Nupélia) at Universidade Estadual de Maringá, for logistic support; to researchers at the Limnology Laboratory of Nupélia for determining water abiotic factors; to Agência Nacional de Águas (ANA); to CNPq/PELD for financial support; and to CAPES for the scholarship granted to the first author.

\section{References}

AGOSTINHO, AA., PELICICE, FM. and GOMES, LC., 2008. Dams and the fish fauna of the Neotropical region: impacts and management related to diversity and fisheries. Revista Brasileira de Biologia = Brazilian Journal of Biology, vol. 68, no. 4 , p. $1119-1132$

AGOSTINHO, AA., PELICICE, FM., PETRY, AC., GOMES, LC. and JÚLIO-JUNIOR, HF., 2007. Fish diversity in the upper Paraná River basin: habitats, fisheries, management and conservation. Aquatic Ecosystem Health \& Management, vol. 10 , no. 2, p. 174-186.

ALVES, GM., VELHO, LFM., LANSAC-TÔHA, FA., ROBERTSON, B. and BONECKER, CC., 2005. Effect of the connectivity on the diversity and abundance of cladoceran assemblages in lagoons of the Upper Paraná River floodplain. Acta Limnologica Brasiliensia, vol. 17, no. 3, p. 317-327.

AOYAGUI, ASM., 2006. Diversidade de rotíferos na planície de inundação do alto rio Paraná (PR/MS - Brasil). Maringá: Universidade Estadual de Maringá. 176p. Tese de Doutorado.
BINI, LM., THOMAZ, SM. and SOUZA, DC., 2001. Species richness and beta diversity of aquatic macrophytes in the Upper Paraná River floodplain. Archiv für Hydrobiologie, vol. 151, no. 3 , p. 511-525.

BONECKER, CC., COSTA, CL., VELHO, LFM. and LANSACTÔHA, FA., 2005. Diversity and abundance of the planktonic rotifers in different environments of the Upper Paraná River Floodplain (Paraná State - Mato Grosso do Sul State, Brazil). Hydrobiologia, vol. 546, no. 1, p. 405-414.

BORGES, PAF., TRAIN, S. and RODRIGUES, LC., 2008. Spatial and temporal variation of phytoplankton in two subtropical Brazilian reservoirs. Hydrobiologia, vol. 607, no. 1, p. 63-74.

BOVO-SCOMPARIN, VM. and TRAIN, S., 2008. Long-term variability of the phytoplankton community in an isolated floodplain lake of the Ivinhema River State Park, Brazil. Hydrobiologia, vol. 610, no. 1, p. 331-344.

CARVALHO, AR., 2007. An ecological economics approach to estimate the value of a fragmented wetland in Brazil (Mato Grosso do Sul state). Revista Brasileira de Biologia = Brazilian Journal of Biology, vol. 67, no. 4, p. 663-671.

CHAZDON, RL., COLWELL, RK., DENSLOW, JS. and GUARIGUATA, MR., 1998. Statistical methods for estimating species richness of woody regeneration in primary and secondary rain forests of Northeastern Costa Rica. In DALLMEIER, F. and COMISKEY, JA. (Eds.). Forest biodiversity research, monitoring and modeling. Washington: The Parthenon Publishing Group. p. 285-309.

COLWELL, RK., 1997. EstimateS: statistical estimation of species richness and shared species from samples. Version 5. User's guide and application. Available from: <http:/viceroy. eeb.uconn.edu/estimates>. Access in: 15 de Janeiro de 2008.

EDLER, L., 1979. Recommendations for marine biological studies in the Baltic Sea: phytoplankton and chlorophyll. Paris: UNESCO. vol. 5, p. 1-38. Working Group 11, Baltic Marine Biologists.

GAUCH Jr., HG. 1986. Multivariate analysis in community ecology. Cambridge: Cambridge University Press. 298p.

GINÉ, MF., BERGAMIN, H., ZAGATTO, EAG. and Reis, BF., 1980. Simultaneus determination of nitrite and nitrate by flow injection analysis. Analytica Chimica Acta, vol. 114, no. 1, p. 191-197.

GOLTERMAN, HL., CLYMO, RS. and OHSTAD, MAM., 1978. Methods for physical and chemical analysis of freshwater. Oxford: Blackwell Scientific Publication. 213p.

HARRISON, S., SALLY, JR. and LAWTON, JH., 1992. Beta diversity on geographic gradients in Britain. Journal of Animal Ecology, vol. 61, no. 1, p. 151-158.

JATI, S. and TRAIN, S., 1994. Euglenaceae pigmentadas de ambientes lênticos da ilha Porto Rico, município de Porto Rico, Paraná, Brasil. Iheringia, vol. 45, no. 1, p. 117-142.

JONGMAN, RHG., TER BRAAK, CJF. and VAN TONGEREN, OFR., 1995. Data analysis in community and landscape ecology. Cambridge: Cambridge University Press. 292p.

MACKERETH, FYH., HERON, JR. and TAILING, JF., 1978. Water analysis: some revised methods for limnologists. Amblesie: Freshwater Biological Association; Titus Wilson \& Sons Ltda. 121p. Scientific Publication, 36. 
McCUNE, B. and MEFFORD, MJ., 1999. Multivariate analysis of ecological data. Version 4. MjM Software Design. Oregon: Gleneden Beach.

McPHADEN, MJ., ZEBIAK, SE. and GLANTZ, MH., 2006. ENSO as an Integrating Concept in Earth Science. Science, vol. 314 , no. 5806 , p. $1740-1745$.

MELO, S. and HUSZAR, VLM., 2000. Phytoplankton in an Amazonian floodplain lake (Lago Batata, Brasil): diel variation and species strategies. Journal of Plankton Research, vol. 22, no. 1 , p. 63-76.

NABOUT, JC., NOGUEIRA, IS. and OLIVEIRA, LG., 2006. Phytoplankton community of floodplain lakes of the Araguaia River, Brazil, in the rainy and dry seasons. Journal of Plankton Research, vol. 28, no. 2, p. 181-193.

NABOUT, JC., NOGUEIRA, IS., OLIVEIRA, LG. and MORAIS, RR., 2007. Phytoplankton diversity (alpha, beta, and gamma) from the Araguaia River tropical floodplain lakes (central Brazil). Hydrobiologia, vol. 557, no. 1, p. 455-461.

NEIFF, JJ., 1990. Ideas para la interpretacion ecologica del Paraná. Interciência, vol. 15, no. 6, p. 424-441.

ROCHA, PC., 2002. Dinâmica dos Canais no Sistema RioPlanície Fluvial do Alto Rio Paraná, nas Proximidades de Porto Rico-PR. Maringá: Universidade Estadual de Maringá. 169p. Tese de Doutorado.

SHANNON, CE. and WEAVER, W., 1963. A mathematical theory of communication. Urbana: University Press. 173p.

SOUZA FILHO, EE. and STEVAUX, JC., 2004. Geology and geomorphology of the Baía-Curutuba-Ivinheima river complex. In THOMAZ, SM., AGOSTINHO, AA. and HAHN, NS. (Eds.). The Upper Paraná river and its floodplain: physical aspects, ecology and conservation. Leiden: Backhuys Publishers. p. $1-29$.

SOUZA FILHO, EE., 2009. Evaluation of the Upper Paraná River discharge controlled by reservoirs. Revista Brasileira de Biologia = Brazilian Journal of Biology, vol. 69, no. (2 suppl), p. 707-716.

SOUZA FILHO, EE., ROCHA, PC., COMUNELLO, E. and STEVAUX, JC., 2004. Effects of the Porto Primavera Dam on physical environment of the downstream floodplain. In THOMAZ, SM., AGOSTINHO, AA. and HAHN, NS. (Eds.). The Upper Paraná River and its floodplain: physical aspects, ecology and conservation. Leiden: Backhuys Publishers. p. 55-74.

STATSOFT INC., 2005. Statistica (data analysis software system). Version 7.1. Available from: <www.statisoft.inc>. Access in: 20 de Outubro de 2007.

THOMAZ, SM., BINI, LM. and BOZELLI, RL., 2007. Floods increase similarity among aquatic habitats in river-floodplain systems. Hydrobiologia, vol. 579, no. 1, p. 1-13.

THOMAZ, SM., PAGIORO, TA., BINI, LM., ROBERTO, MC. and ROCHA, RRA., 2004a. Limnology of the upper Paraná floodplain habitats: patterns of spatio-temporal variations and influence of the water levels. In AGOSTINHO, AA., RODRIGUES, L., GOMES, LC., THOMAZ, SM. and
MIRANDA, LE. (Eds.). Structure and functioning of the Paraná River and its floodplain. Maringá: EDUEM. p. 37-42.

THOMAZ, SM., PAGIORO, TA., BINI, LM., ROBERTO, MC. and ROCHA, RRA., 2004b. Limnological characterization of the aquatic environments and the influence of hydrometric levels. In THOMAZ, SM., AGOSTINHO, AA. and HAHN, NS. (Eds.). The Upper Paraná River floodplain: physical aspects, ecology and conservation. Leiden: Backhuys Publishers. p. 75-102.

THOMAZ, SM., PAGIORO, TA., BINI, LM. and SOUZA, DC., 2004c. Aquatic macrophytes from the Upper Paraná River Floodplain: species list and patterns of diversity in large scale. In AGOSTINHO, AA., RODRIGUES, L., GOMES, LC., THOMAZ, SM. and MIRANDA, LE. (Eds.). Structure and functioning of the Paraná River and its floodplain. Maringá: EDUEM. p. 221-225.

TRAIN, S. and RODRIGUES, LC., 1998. Temporal fluctuations of the phytoplankton community of the Baía River, in the Upper Paraná River floodplain, Mato Grosso do Sul, Brazil. Hydrobiologia, vol. 361, no. 1, p. 125-134.

TRAIN, S. and RODRIGUES, LC., 2004. Phytoplankton assemblages. In THOMAZ, SM., AGOSTINHO, AA. and HAHN, NS. The Upper Paraná River floodplain: physical aspects, ecology and conservation. Leiden: Backhuys Publishers. p. 103-124.

TRAIN, S., RODRIGUES, LC., BOVO, VM., BORGES, PAF. and PIVATO, BM., 2004. Phytoplankton composition and biomass in environments of the Upper Paraná River. In AGOSTINHO, AA., RODRIGUES, L., GOMES, LC., THOMAZ, SM. and MIRANDA, LE. (Eds.). Structure and functioning of the Paraná River and its floodplain. Maringá: EDUEM. p. 63-74.

TRAIN, S., JATI, S., RODRIGUES, LC. and PIVATO, BM., 2005. Distribuição espacial e temporal do fitoplâncton em três reservatórios da Bacia do Rio Paraná. In RODRIGUES, L., THOMAZ, SM., AGOSTINHO, AA. and GOMES, LC. Biocenoses em reservatórios: padrões espaciais e temporais. São Carlos: RIMA. p. 73-85.

TRAIN, S., RODRIGUES, LC., JATI, S., BOVO-SCOMPARIN, VM., MARENGONI, E., BORSALLI, CCJ. and BORGES, PAF., 2007. Fitoplâncton: a planície de inundação do Alto Rio Paraná. Programa PELD/CNPq sítio 6 - Relatório Anual. Available from: <http://www.peld.uem.br/Relat2007/pdf/ capitulo_3.pdf>. Access in: 10 de Março de 2008.

UTERMÖHL, H., 1958. Zur Vervollkommnung der quantitativen phytoplankton-methodic. Mitteilungen Internationale Vereinigung für Theoretische und Angewandte Limnologie, vol. 9 , no. 1, p. 1-38.

VELHO, LFM., BINI, LM. and LANSAC-TÔHA, FA., 2004. Testate amoeba (Rhizopoda) diversity in plankton of the Upper Paraná River floodplain, Brazil. Hydrobiologia, vol. 523, no. 1-3, p. 103-111.

WARD, JV., TOCKNER, K. and SCHIEMER, F., 1999. Biodiversity of floodplain river ecosystems: ecotones and connectivity. Regulated Rivers: Research \& Managment, vol. 15 , no. 1-3, p. 125-139.

WETZEL, RG. and LIKENS, GE., 2000. Limnological analyses. New York: Springer-Verlag. 429p. 